\title{
Glassmaking using natron from el-Barnugi (Egypt); Pliny and the Roman glass
}

industry

\section{M. Jackson, S. Paynter, M.-D. Nenna \& P. Degryse}

Archaeological and Anthropological Sciences

ISSN 1866-9557

Archaeol Anthropol Sci

DOI 10.1007/s12520-016-0447-4

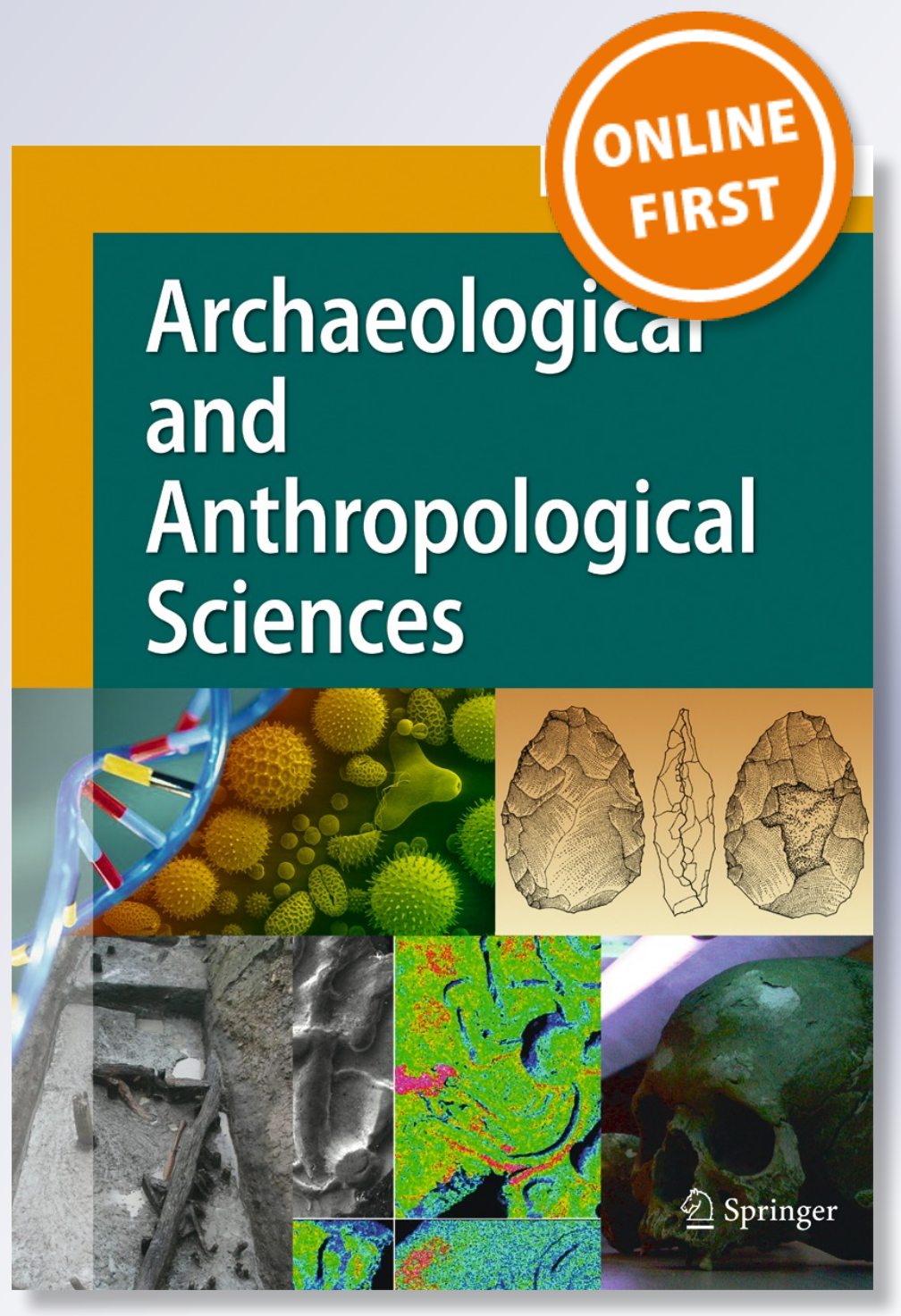

脰 Springer 
Your article is published under the Creative Commons Attribution license which allows users to read, copy, distribute and make derivative works, as long as the author of the original work is cited. You may selfarchive this article on your own website, an institutional repository or funder's repository and make it publicly available immediately. 


\title{
Glassmaking using natron from el-Barnugi (Egypt); Pliny and the Roman glass industry
}

\author{
C. M. Jackson ${ }^{1} \cdot$ S. Paynter ${ }^{2}$ - M.-D. Nenna ${ }^{3} \cdot$ P. Degryse ${ }^{4}$
}

Received: 16 August 2016 / Accepted: 27 November 2016

(C) The Author(s) 2016. This article is published with open access at Springerlink.com

\begin{abstract}
Pliny the Elder describes the discovery of a process for making natron glass, which was widely used for much of the first millennium $\mathrm{BC}$ and $\mathrm{AD}$. His account of glassmaking with natron has since been corroborated by analyses of archaeological glass and the discovery of large-scale glass production sites where natron glass was made and then exported. Analyses of Egyptian natron have shown it to be a complex mixture of different sodium compounds, and previous experiments to make glass with Egyptian natron have been unsuccessful. Here, natron from el-Barnugi in the Egyptian Nile delta, a site which also probably supplied Roman glassmakers, is used to produce glass. The experiments show that highquality glass, free of unreacted batch or bubbles, could have been produced from natron in its unprocessed form in a single stage, that larger quantities of natron would be required than has previously been anticipated, that the presence of different sodium-containing compounds in the deposit aided melting, and that negligible waste is produced. The implications for the identification of glass production sites, for the organisation of trade and for the supply of natron within and outside Egypt are discussed in the light of Pliny's accounts.
\end{abstract}

C. M. Jackson

c.m.jackson@sheffield.ac.uk

1 Department of Archaeology, University of Sheffield, Northgate House, West Street, Sheffield S1 4ET, UK

2 Historic England, Fort Cumberland, Fort Cumberland Road, Eastney, Portsmouth PO4 9LD, UK

3 Laboratoire HiSoMA, Maison de l'Orient et de la Méditerranée, 7 rue Raulin, 69365 Lyon Cedex 07, France

4 Division of Geology, Centre for Archaeological Sciences, Celestijnenlaan 200 E, 3001 Heverlee, Belgium
Keywords Natron · Roman glass $\cdot$ Pliny $\cdot$ Trade $\cdot$ Glass composition

\section{Introduction}

In the first century AD, Pliny the Elder discusses the use of natron 'preferably Egyptian soda' for the production of Roman glass (Pliny Natural History (NH) XXXI, 107 and XXXVI, 193-194). The soda was the key to this glassmaking process because it reacted with the sand to form a melt at temperatures within the reach of ancient furnaces, with the soda essentially acting as a flux. Consequently, it has been accepted that natron was the alkali used for Roman glass production and that Wadi Natrun, the most well-known evaporitic lake in modern Egypt, was the primary source of the evaporite flux. Chemical analysis of Roman glasses corroborates the use of such salts, because mineral soda, such as natron or trona, derived from salt lakes, would account for the high soda content, low potash, magnesia and phosphorus concentrations and low levels of other impurities in the glass.

\section{Sources of soda used in Roman glass production}

Although the soda mentioned by Pliny from Egypt is one potential source, there are other sources of natron within the southern Mediterranean, Near East and Africa, which may have supplied the alkali flux necessary to produce Roman soda-lime-silica glasses (NH XXXI, 107, Cosson 1936, Wilkinson 1843, Jones 1928, 327, Lucas 1912, 1932, Lucas and Harris 1962, Parkinson 1914, Ignatiadou et al. 2005, Dardeniz 2015 and those reviewed in Shortland et al. 2006). However, as it is likely that glass production took place near the sources of the primary raw materials, those in Egypt, where Roman glassmaking installations have been found 
(Nenna 2015), remain the most likely sources used in the eastern Mediterranean.

In a different section of his Natural History, Pliny mentions two different Egyptian sources used for glassmaking: the soda beds around Naukratis, which he suggests are superior, and those near Memphis (NH XXXI, 111). Locating these in the modern landscape and relating them to present-day lakes, such as those at the Wadi Natrun (NH XXXI), may be inferred by combining a number of lines of research. Lucas and Harris (1962, 265-266) suggest that the natron at Memphis probably relates to the deposits at Wadi Natrun and those at Naukratis (the ancient Greek city) to the smaller deposits from elBarnugi. This may be tentatively supported by more recent survey in the late 1970 s of all ancient sites within a $25-\mathrm{km}$ radius of Naukratis in the western Nile Delta, along the Nile from el-Barnugi in the north to Kom el-Hisn in the south (Coulson and Leonard 1979). At el-Barnugi it is noted that there were abundant Cypriot ceramic sherds which would date occupation to the late Roman period, and 'pale green glass, crucible fragments and both glass and metal slag... may indicate the existence of an industrial establishment in this area' (Coulson and Leonard 1979, 163). New surveys done in the 2000 s could not identify any evidence connected to raw glass manufacture in el-Barnugi and its vicinity (Nenna et al. 2005, 59), but that does not diminish the fact that the lakes around Barnugi were probably providers of natron in antiquity and in the Medieval Period (Décobert 2003). Since the remarks of White (1932, quoted in Cosson 1936, 116) that 'Nitria was almost universally, though wrongly, identified with Wadi el Natrun' it is well accepted that the ancient locality, called Nitria, was wrongly identified as Wadi Natrun and that the locality of Pernoudj or el-Barnugi was the best candidate. Although Pliny suggests that the natron from Wadi Natrun (Memphis) was inferior to that from el-Barnugi (Naukratis), Lucas (1932) dismisses this based upon modern excavation of natron at the bottom of deeper lakes in the Wadi. Moreover, the archaeological remains at el-Barnugi would align with the status of Naukratis as a thriving trading post from the seventh century BC until Roman times, which connected with many parts of the Hellenistic and later Roman Empires. Therefore, the deposits at el-Barnugi may be one source exploited in the Roman period to produce glass; its potential use for glass manufacture in the Roman period is explored in this paper.

\section{Provenancing natron sources}

It is difficult to determine which natron deposits were used in antiquity. Major element analysis yields few clues to provenance as the salts are predominantly sodium, but trace elements and isotopes are potentially useful. The trace element composition of the glass is related to that of the raw materials, and hence a match to local geological resources can indicate the manufacturing location. However, natron is a heterogeneous material and the major and trace element composition of a single natron source is highly variable (see discussion below). In addition, some of the components have limited solubility in the glass and so the composition of the original natron is not reflected in the final product. These factors limit the usefulness of chemical composition for identifying the natron source (Brems and Degryse 2013). Isotope ratios have been increasingly used to characterise glass raw materials: neodynium $(\mathrm{Nd})$ isotopes, predominantly associated with sand deposits, have been successfully used to show that the manufacturing regions for some Roman glasses were in the eastern Mediterranean, and strontium $(\mathrm{Sr})$ isotopes have been used to investigate the source of the calcium in the glass (see Brems et al. 2014). Boron (B) is found in the natron flux and current investigations have used this as a potential key to the provenance of soda deposits (Devulder et al. 2014) but it is also found in the sand, and so the interpretation relating its incorporation in the glass remains problematic. Difficulties of provenancing arise however if raw material deposits show similarities across large geographical areas, and this may be the case for natron samples from Egypt (Devulder et al. 2014) and north Africa (Degryse 2014, 94).

\section{The composition of natron and suitability for glassmaking}

Not all natron deposits are the same, and even within the same locality the composition changes seasonally and through the sediment (Wilkinson 1843, Lucas and Harris 1962, Shortland et al. 2011). Sources typically contain a mixture of sodium compounds including carbonates, bicarbonates, sulphates and chlorides. The reactive proportion used to flux the sand that the glassmakers require is 'natron' $\left(\mathrm{Na}_{2} \mathrm{CO}_{3} \cdot 10 \mathrm{H}_{2} \mathrm{O}\right)$ or 'trona' $\left(\mathrm{Na}_{2} \mathrm{CO}_{3} \cdot \mathrm{NaHCO}_{3} \cdot 2 \mathrm{H}_{2} \mathrm{O}\right)$ (and potentially pirsonnite, also a carbonate-containing calcium, $\mathrm{Na}_{2} \mathrm{CO}_{3} \cdot \mathrm{CaCO}_{3} \cdot 2 \mathrm{H}_{2} \mathrm{O}$ ), but the other soda-rich minerals, also precipitated, contain sulphates and chlorides which are only partially reactive or 'practically unreactive', in glass melting (Turner 1956, 291T). These might include thermonatrite $\left(\mathrm{Na}_{2} \mathrm{CO}_{3} \cdot \mathrm{H}_{2} \mathrm{O}\right)$, nahcolite $\left(\mathrm{NaHCO}_{3}\right)$, burkeite $\left(\mathrm{Na}_{6}\left(\mathrm{CO}_{3}\right)\left(\mathrm{SO}_{4}\right)_{2}\right)$, thenardite $\left(\mathrm{Na}_{2} \mathrm{SO}_{4}\right)$, mirabilite $\left(\mathrm{Na}_{2} \mathrm{SO}_{4} \cdot 10 \mathrm{H}_{2} \mathrm{O}\right)$ and halite $(\mathrm{NaCl})($ see Shortland 2004 for a review).

The solubility of chlorine in glass is low and is dependent on the melting regime and the composition of the glass, in particular the calcium oxide content, rather than the total amount of salt available. Bateson and Turner (1939) determined that in a soda-lime-silica matrix, the maximum concentration of chlorine in the resulting glasses, regardless of the amount of sodium chloride added, was $1.42 \mathrm{wt} \%$ (melted at $1400{ }^{\circ} \mathrm{C}$ ); a concentration of up to $1.8 \mathrm{wt} \%$ was observed by Tanimoto and Rehren (2008).

The relative insolubility of the chlorides and sulphates in glass has led Freestone $(2006,203)$ and Nenna $(2015,16)$ to propose that any excess sodium chloride and sulphate would 
separate as an immiscible layer on the surface of the natron glass, which could be skimmed off during melting or discarded after the glass had cooled. Tanimoto and Rehren (2008) also propose something similar, that a glass with a eutectic mixture would result (a mixture with a lower melting temperature than any other combination of the same constituents). The eutectic composition would be dependent on the melting temperature and the raw materials used (Rehren 2000); an immiscible, chlorine-rich layer would also form on the surface of the glass, although alkalis could exchange between these two melts.

However, although the chlorides and sulphates are poorly soluble, their combined presence together with the carbonates may still influence the predicted melting behaviour of the whole. Shelby $(1997,36)$ suggests that changes in batch raw materials, even relatively unreactive ones, can accelerate the melting process. If a small portion of sodium sulphate is present, some of the sodium carbonate may be replaced, speeding up the dissolution of the sand as lower-temperature eutectic mixtures are formed; the subsequent release of $\mathrm{SO}_{3}$ aids homogenisation. This reaction presumes that only small quantities of sodium sulphate will be used and thus contribute only small quantities of sodium to the melt. This effect is also true for $\mathrm{NaCl}$ at higher temperatures, and water (included in water of crystallisation in the natron) will also act as an accelerant to the process by reducing the viscosity. Thus, the presence of sodium sulphate, sodium chloride and water should result in a shorter batch-free time, i.e. reduce the melting time and hence fuel consumption (Shelby 1997, 36). All of these compounds promote the reaction of the batch but may not be incorporated into the melt in large quantities themselves.

The experimental work undertaken on the salts recovered from Lake Fazda, Wadi Natrun, in September 2006, showed that the sample was predominantly halite and burkeite rich (ratios varied) with only one sample containing trona at $79 \%$ (Shortland et al. 2006, Shortland et al. 2011). Melts made with this material at temperatures up to $1200{ }^{\circ} \mathrm{C}$ and $24 \mathrm{~h}$, as typically quoted for Roman glass melting (Turner 1956), failed to produce a glass. The authors suggest that either the salt composition of the lake had altered over time, or more probably that the sulphur-rich deposits were processed in antiquity, in a method similar to the 'Leblanc' method of the eighteenth and nineteenth centuries. This would convert the sulphate phases to carbonates, which could readily be used for glass production. However, there are other reasons relating to the composition of the natron which caused these experiments to fail and these are explored in the following.

\section{Aims}

This paper explores the composition of a sample of natron from el-Barnugi. The aims were: to characterise the natron source, to investigate the properties of the natron collected to assess whether it could be used to produce a glass at melting temperatures easily achievable for Roman glassmakers, and to produce glass of a typical Roman composition with, or without, raw material pre-treatment. Experimental melts were conducted to determine the presence and amount of reactive components in the natron, what proportions of raw materials were needed and what effect the unreactive components would have on the glass made. The observations made when using natron as the flux were then further explored by producing experimental model glasses. The results are used to better understand contemporary accounts of Roman glass production and the archaeological remains of the industry.

\section{Materials and methodology}

\section{Analytical methods for the raw materials and experimental glasses}

As natron is principally composed of crystalline compounds, powder X-ray diffraction analysis using a Bruker D8 Advance, at $40 \mathrm{~mA}$ and $40 \mathrm{kV}$, with a step size of 0.02 , from 10 to $80^{\circ}$, was used to identify the compounds present. Each natron sample differs slightly because they are formed by an evaporative process. The proportions of the different compounds present were approximated based on the relative intensity ratio (RIR) values when compared to known mixtures in standards (Dinnebier and Billinge 2008, 303). This quantification method is only semi-quantitative, but nevertheless, the estimate of the sodium carbonate content was found to be relatively accurate because this was used as the basis of the calculations for proportions of each raw material in the experimental glass batches, which formed glasses with the predicted compositions.

Major and minor elements were measured by an FEI Inspect Scanning Electron Microscope (SEM) with an attached energy-dispersive spectrometer at Historic England, UK. Analytical conditions, sample preparation methods and precision/accuracy are given in Paynter et al. 2015, checked against Corning glass standards. The tabulated results are averages of at least 3 analyses and normalised. The compositional data for natron are used only semi-quantitatively in calculations because of the heterogeneity of the material.

Trace elements, in solution, were determined using an Agilent 7500c inductively coupled plasma-mass spectrometer (ICP-MS) instrument at Imperial College, Ascot. The solution was transported to the plasma source using the gas flow control system at a flow rate of $1.51 \mathrm{~min}^{-1}$ and the plasma operated at a power of $1500 \mathrm{~W}$. Analyses were calibrated against the NIST SRM 610 glass reference material, doped with a nominal concentration of $500 \mathrm{ppm}$ for most trace elements, using the consensus values (Pearce et al. 1997), and checked 
with NIST SRM 612. Trace elements show a good correspondence with the consensus values for NIST 612 (Pearce et al. 1997), and both precision and accuracy are good (below $10 \%$, many below $5 \mathrm{wt} \%$ ) for the trace elements measured.

Strontium and boron isotope measurements were undertaken at KU Leuven. Instrumentation, running parameters and sample preparation methods are given in Degryse and Schneider (2008) and Devulder et al. (2014).

\section{Materials for experimental melts}

Several experimental batches were prepared, described in detail below: the first set of 'natron experimental glasses' containing el-Barnugi natron, L30A sand (Table 1) and laboratory-grade calcium carbonate, and the second set of 'model experimental glasses' using laboratory-grade sodium bicarbonate, sodium chloride and sodium sulphate instead of natron, to better understand how the presence of chlorides and sulphates affects the melt.

The natron used in this study was some already harvested by local workers, stored at the edge of the lake and ready for use; therefore although the collection date was winter/spring (2001), it may have been harvested much earlier, possibly in the summer of the previous season. Sodium salts precipitate out of the brines during the hottest part of the summer. Pliny (NH XXXI, 107) suggests that soda was collected in Macedonia (not necessarily for glassmaking) when the dog star rises, which is summer in Greece, and at the summer solstice, just before the Nile flooded, in Egypt, but the information gathered through the travellers' accounts and the memorandum of General Andreossi during the Expédition d'Égypte indicates that a period between mid-November and mid-March is more likely (Nenna 2015, 17). The natron is analysed and characterised in the first part of the results section below.
The batches were melted in mullite-rich crucibles (Table 2).

\section{Experimental glass manufacturing methods}

To manufacture 'typical' Roman glass, the composition was approximated to a three-component melt, with $70 \mathrm{wt} \%$ silica, $20 \mathrm{wt} \%$ soda and $10 \mathrm{wt} \%$ lime. Other components (generally present as impurities in the raw materials) were not included in the mixture as the test was to ascertain the relative proportions of soda needed to produce a glass of this composition. The reduction of the glass to three components means that the soda and calcium oxide are slightly overrepresented, as soda is generally in the region of $18 \mathrm{wt} \%$ and calcium oxide around 8 wt\% in Roman glass, but it is a good approximation. Pliny (NH XXXVI, 194) suggests that sand is mixed with three parts of soda, 'either by weight or by measure' and this is explored below (Smedley and Jackson 2002, Degryse 2014, 47).

\section{The natron experimental glasses}

The percentage of sodium bicarbonate in the natron was estimated from the XRD and SEM-EDS results (Results section) at around $40 \mathrm{wt} \%$, and this provided a basis for the batch calculations for the experimental melts. The proportions of sodium chloride and sulphate in the natron were more variable but found often to be in equal proportions; Shelby (1997), Turner (1956) and Bateson and Turner (1939) noted that chlorides and sulphates had limited solubility but a potential role in glass formation. To test the contribution and solubility of each component in the natron it was assumed that the bicarbonate would be fully soluble but the chlorides and sulphates
Table 1 Analysed composition of L30A Lochaline sand

\begin{tabular}{llllll}
\hline Oxide & Concentration (wt\%) & Element & Concentration (ppm) & Element & Concentration (ppm) \\
\hline $\mathrm{SiO}_{2}$ & 99.64 & $\mathrm{~V}$ & $<1.4$ & $\mathrm{Zr}$ & 14.2 \\
$\mathrm{Na}_{2} \mathrm{O}$ & 0.32 & $\mathrm{Cr}$ & 32.1 & $\mathrm{Nb}$ & 0.5 \\
$\mathrm{CaO}$ & $<\mathrm{LLD}$ & $\mathrm{Co}$ & $<1.2$ & $\mathrm{Mo}$ & 0.3 \\
$\mathrm{MgO}$ & 0.02 & $\mathrm{Ni}$ & $<0.8$ & $\mathrm{Ag}$ & 0.2 \\
$\mathrm{~K}_{2} \mathrm{O}$ & $<\mathrm{LLD}$ & $\mathrm{Cu}$ & 1.2 & $\mathrm{Cd}$ & $<0.2$ \\
$\mathrm{Al}_{2} \mathrm{O}_{3}$ & $<\mathrm{LLD}$ & $\mathrm{Zn}$ & 2.8 & $\mathrm{Sn}$ & $<0.2$ \\
$\mathrm{P}_{2} \mathrm{O}_{5}$ & $<\mathrm{LLD}$ & $\mathrm{Ga}$ & $<0.3$ & $\mathrm{Sb}$ & $<0.3$ \\
$\mathrm{TiO}_{2}$ & 0.01 & $\mathrm{Ge}$ & 0.8 & $\mathrm{I}$ & 1.1 \\
$\mathrm{Fe}_{2} \mathrm{O}_{3}$ & $<\mathrm{LLD}$ & $\mathrm{As}$ & $<0.3$ & $\mathrm{Cs}$ & $<1.0$ \\
$\mathrm{MnO}$ & $<\mathrm{LLD}$ & $\mathrm{Cl}$ & $\mathrm{Ba}$ & 3.3 \\
$\mathrm{SO}_{3}$ & $<\mathrm{LLD}$ & $\mathrm{Se}$ & $\mathrm{C}$ & $\mathrm{Pb}$ & 1.2 \\
& & $\mathrm{Br}$ & 0.3 & $\mathrm{Bi}$ & $<0.4$ \\
& & $\mathrm{Rb}$ & $<0.2$ & $\mathrm{Th}$ & 0.9 \\
& & $\mathrm{Sr}$ & 2.0 & $\mathrm{U}$ & $<0.7$ \\
\hline
\end{tabular}


Table 2 Composition of mulliterich crucible (measured by SEMEDS, normalised average)

\begin{tabular}{lllllllllll}
\hline $\mathrm{Na}_{2} \mathrm{O}$ & $\mathrm{MgO}$ & $\mathrm{Al}_{2} \mathrm{O}_{3}$ & $\mathrm{SiO}_{2}$ & $\mathrm{P}_{2} \mathrm{O}_{5}$ & $\mathrm{SO}_{3}$ & $\mathrm{Cl}$ & $\mathrm{K}_{2} \mathrm{O}$ & $\mathrm{CaO}$ & $\mathrm{TiO}_{2}$ & $\mathrm{Fe}_{2} \mathrm{O}_{3}$ \\
\hline 0.85 & 0.39 & 42.17 & 53.41 & $<$ LLD & $<$ LLD & $<$ LLD & 1.40 & 0.16 & 0.18 & 1.08 \\
\hline
\end{tabular}

would not be. Thus, three batches were prepared. Batch (1) assumed that only the trona would react with the sand and that the sulphate and chloride would be unreactive, and batches (2) and (3) that the chlorides and sulphates might partially react or be totally unreactive. Molar calcu-lations were performed to determine the amount of natron to be used in each batch, which was highest in batch (1) and lowest in batch (3). This meant that batch (1) had significantly larger amounts of the elBarnugi soda added than (3), with (2) an intermediate measure. Batch weight (and hence size) varied depending upon the amount of soda added, but no batches weighed more than $25 \mathrm{~g}$.

The natron glass batches were heated for $12 \mathrm{~h}$ at $1300^{\circ} \mathrm{C}$ to ascertain which, if any, would produce a batch-free melt. Although it is unlikely that these temperatures were reached in antiquity, the tests were performed to see if any of the mixtures could produce glass, cf. Shortland et al. (2011). Only natron batch (1) successfully formed a glass, and so the experiment was repeated at lower temperatures to test the minimum temperatures and times needed to achieve a batch-free melt (procedures followed were those reported in Jackson and Smedley 2004). It has been suggested that the temperature required to form a batch-free Roman glass is in the region of $1100{ }^{\circ} \mathrm{C}$ (Turner 1956, Silvestri et al. 2006).

\section{Model experimental glasses}

Three model glass batches were prepared using laboratory reagents, each containing the appropriate quantities of sand, calcium carbonate and sodium bicarbonate to give an approximate Roman glass composition; one batch also contained sodium chloride, another contained sodium sulphate, and the final batch contained both chloride and sulphate in equal proportions (Table 3). These batches were melted at $1100^{\circ} \mathrm{C}$ for $12 \mathrm{~h}$.

All of the glass batches were melted in mullite-rich crucibles (Table 2) in a silicon carbide furnace, according to the method of Jackson and Smedley (2004).

Table 3 Proportions of sodium salts used for model glasses

\begin{tabular}{llllll}
\hline $\begin{array}{l}\text { Lab. } \\
\text { reagent } \\
\text { melts }\end{array}$ & $\begin{array}{l}\text { Sodium } \\
\text { chloride } \\
(\mathrm{g})\end{array}$ & $\begin{array}{l}\text { Sodium } \\
\text { sulphate } \\
(\mathrm{g})\end{array}$ & $\begin{array}{l}\text { Sodium } \\
\text { bicarbonate } \\
(\mathrm{g})\end{array}$ & $\begin{array}{l}\text { Sand } \\
(\mathrm{g})\end{array}$ & $\begin{array}{l}\text { Calcium } \\
\text { carbonate } \\
(\mathrm{g})\end{array}$ \\
\hline 1 & 54.2 & 41.7 & 43.1 & 70 & 17.85 \\
2 & 54.2 & & 43.1 & 70 & 17.85 \\
3 & & 41.7 & 43.1 & 70 & 17.85 \\
\hline
\end{tabular}

\section{Results}

\section{Characterisation of the natron}

\section{1) Trace elements}

The trace element composition of the sample of natron from el-Barnugi shows that very few elements are present at concentrations above the detection limit (Table 4). The concentrations of barium, strontium and zirconium, which are the trace elements (and isotopes) typically used in Roman glass

Table 4 Trace elements in natron from el-Barnugi

\begin{tabular}{|c|c|c|c|c|}
\hline Element & 612 Quoted & $\%$ SD (Precision) & Accuracy & Soda \\
\hline [B] & & & & $11.6^{\mathrm{a}}$ \\
\hline $52 \mathrm{Cr}$ & 39.8 & 1.2 & -8.7 & $<\mathrm{LLD}$ \\
\hline $59 \mathrm{Co}$ & 35.26 & 2.2 & -1.7 & 1.218 \\
\hline $63 \mathrm{Cu}$ & 36.71 & 5.3 & 1.1 & 15.737 \\
\hline $71 \mathrm{Ga}$ & 36.24 & 1.3 & -6.0 & $<\mathrm{LLD}$ \\
\hline $85 \mathrm{Rb}$ & 31.63 & 0.9 & -12.3 & $<$ LLD \\
\hline $88 \mathrm{Sr}$ & 76.15 & 0.9 & -4.0 & 9.330 \\
\hline $89 \mathrm{Y}$ & 38.25 & 1.3 & -11.4 & 0.247 \\
\hline $90 \mathrm{Zr}$ & 35.99 & 4.0 & -18.2 & 6.391 \\
\hline $135 \mathrm{Ba}$ & 37.74 & 3.7 & 1.3 & 7.527 \\
\hline $139 \mathrm{La}$ & 35.77 & 2.2 & -10.3 & $<\mathrm{LLD}$ \\
\hline $140 \mathrm{Ce}$ & 38.35 & 2.1 & -6.7 & 0.651 \\
\hline $141 \mathrm{Pr}$ & 37.16 & 1.9 & -5.9 & $<$ LLD \\
\hline $146 \mathrm{Nd}$ & & 3.6 & & 0.271 \\
\hline $147 \mathrm{Sm}$ & 36.72 & 2.8 & -6.3 & $<$ LLD \\
\hline $151 \mathrm{Eu}$ & 34.44 & 1.3 & -3.7 & $<$ LLD \\
\hline $157 \mathrm{Gd}$ & 36.95 & 3.0 & 0.4 & $<\mathrm{LLD}$ \\
\hline $159 \mathrm{~Tb}$ & 35.92 & 0.8 & -2.2 & $<$ LLD \\
\hline 163 Dy & 35.97 & 4.5 & -10.0 & 0.096 \\
\hline $165 \mathrm{Ho}$ & 37.87 & 1.2 & -5.1 & $<$ LLD \\
\hline $167 \mathrm{Er}$ & 37.43 & 2.7 & -7.5 & $<$ LLD \\
\hline $169 \mathrm{Tm}$ & 37.55 & 1.7 & -6.3 & $<\mathrm{LLD}$ \\
\hline $172 \mathrm{Yb}$ & 39.95 & 5.0 & -10.4 & 0.040 \\
\hline $175 \mathrm{Lu}$ & 37.71 & 0.3 & -7.4 & $<\mathrm{LLD}$ \\
\hline $181 \mathrm{Ta}$ & 39.77 & 0.7 & -6.9 & $<$ LLD \\
\hline $232 \mathrm{Th}$ & 37.23 & 2.2 & -3.7 & 0.180 \\
\hline $238 \mathrm{U}$ & 37.15 & 1.4 & -5.6 & 2.641 \\
\hline
\end{tabular}

The isotope (number) is shown next to the element symbol; negative values for accuracy indicate that the measurements were lower than expected

$<L L D$ below detection

${ }^{a}$ Measured by Devulder and discussed by Devulder et al. (2014) 
provenance studies, are low (7, 9 and 6 ppm respectively) and would not significantly contribute to the bulk glass composition. The majority of the REEs are below detection limits except for $\mathrm{Ce}, \mathrm{Pr}, \mathrm{Nd}$, Dy and $\mathrm{Yb}$, and their contribution to the resulting glass composition is effectively negligible. Therefore, the trace element concentrations in this sample of natron would not significantly alter the trace element concentrations in the final glass; by far the largest contributor to this would be the sand.

\section{2) Isotopes}

The $\mathrm{Sr}$ isotope signature in the natron from el-Barnugi is ${ }^{87} \mathrm{Sr} /{ }^{86} \mathrm{Sr}=0.70816$. This is comparable with isotope signatures for other evaporite samples collected from Lake Fazda in Wadi Natrun (range ${ }^{87} \mathrm{Sr} /{ }^{86} \mathrm{Sr} 0.70804-0.70816$, with one outlier at 0.70924$)$. This signature probably derives from the source of the water from which these salt deposits originate, pointing to the underlying Miocene aquifer (Shortland et al. 2011). The Sr in all of the natron analysed so far has been systematically low ( $\mathrm{Sr}<10 \mathrm{ppm})$. It is therefore unlikely that this flux source has a significant effect on the $\mathrm{Sr}$ isotopic composition of the glass; Roman glass has $\mathrm{Sr}$ contents of a few hundred parts per million.

Boron is a more promising isotope for the provenance determination of flux sources. The isotope ratio for $\delta^{11} \mathrm{~B}$ (expressed as per mil $(\%)$ relative to the isotopic value of the standard) has been measured as $28.5 \% \circ \delta^{11} \mathrm{~B}$ with a total B content of $11.6 \mathrm{ppm}$ (Devulder et al. 2014). The measured $\delta^{11} \mathrm{~B}$ values for Egyptian natron have a range of $24-35 \%$, and the boron content varies considerably within the range 6$180 \mu \mathrm{g} / \mathrm{g}$, which puts the el-Barnugi natron sample in the (lower) range of other natron deposits from Wadi Natrun and Fezzan, both in terms of boron content and isotopic composition. Boron is also present in sand however, and analyses of a number of sand samples have been published which in terms of $\delta^{11} \mathrm{~B}$ isotope ratio show negative values of $-10-0 \%$ when normalised to the continental crust, and so Devulder et al. (2014) argue that the $\delta^{11} \mathrm{~B}$ of the resulting glass will be lower than that of the flux alone. In terms of boron, the el-Barnugi natron sample is therefore consistent with others analysed from the region.

\section{3) The mineralogical components}

Whilst the provenance of the natron from el-Barnugi is of archaeological interest, its reactivity and suitability for glass production have to be demonstrated, in terms of the melting temperature and the quality of the final product. Semiquantitative analysis using SEM-EDS showed that the sample is composed predominantly of soda but also contains low concentrations of $\mathrm{SiO}_{2}, \mathrm{MgO}, \mathrm{Al}_{2} \mathrm{O}_{3}, \mathrm{CaO}$ and $\mathrm{Fe}_{2} \mathrm{O}_{3}$ (Table 5). These results correspond very well with other analyses of Egyptian natron, such as samples from Egyptian tombs (Brill 1999), and also show the same range of sulphate to chloride proportions, either approximately equal or with chloride dominating.

Semi-quantitative XRD analysis of the sample identified three sodium compounds (Fig. 1). The essential mineral for glass production, trona $\left(\mathrm{Na}_{3} \mathrm{H}\left(\mathrm{CO}_{3}\right)_{2} \cdot 2 \mathrm{H}_{2} \mathrm{O}\right)$, constituted approximately $40 \mathrm{wt} \%$ of the total, consistent with the sample analysed by SEM-EDS (and confirmed by the composition of the experimental glass made from the natron, below). The other two components, thenardite $\left(\mathrm{Na}_{2} \mathrm{SO}_{4}\right)$ and halite $(\mathrm{NaCl})$ make up the remainder, sometimes with halite dominant. Since the sample was taken from a much larger heterogeneous deposit, variation is likely to occur.

\section{3) Density}

To better understand Pliny's statement 'by weight or by measure' (NH XXXVI, 194), the density of the natron from elBarnugi was also measured. Without compacting the natron and measuring it as powder, the density was approximately $1 \mathrm{~g} / \mathrm{cm}^{3}$.

\section{Characterisation of the natron experimental glass}

Of the natron glass batches heated at $1300^{\circ} \mathrm{C}$ it can be seen in Fig. 2 that only the glass with the largest proportion of trona, batch (1), formed a batch-free glass. As Turner (1956) noted, this confirms that sodium sulphate and sodium chloride do not react in any significant quantity, since the other mixtures did not produce a fully formed glass, even at high melting temperatures. Batch (1) also resulted in a batch-free glass when heated at a lower temperature of $1100^{\circ} \mathrm{C}$ for $12 \mathrm{~h}$ (Fig. 3). The glass shows a brilliance, is colourless because of the very pure modern glassmaking sands used in production, but also has no discernible insoluble, or unmelted, components even when melted at $1100{ }^{\circ} \mathrm{C}$. When batch (1) was heated at $1000{ }^{\circ} \mathrm{C}$ for $12 \mathrm{~h}$, it resulted in only a partial melt, suggesting that longer times were needed, or that the sample may not make a homogenous batch-free melt at this temperature.
Table 5 Major and minor elements in natron from elBarnugi (measured by SEMEDS)

\begin{tabular}{lllllllllll}
\hline Oxide & $\mathrm{SiO}_{2}$ & $\mathrm{Na}_{2} \mathrm{O}$ & $\mathrm{CaO}$ & $\mathrm{MgO}$ & $\mathrm{K}_{2} \mathrm{O}$ & $\mathrm{Al}_{2} \mathrm{O}_{3}$ & $\mathrm{Fe}_{2} \mathrm{O}_{3}$ & $\mathrm{TiO}_{2}$ & $\mathrm{Cl}$ & $\mathrm{SO}_{3}$ \\
\hline wt\% & 0.8 & 52.0 & 0.3 & 0.4 & $<$ LLD & 0.2 & 0.2 & $<$ LLD & 42.5 & 3.5 \\
\hline
\end{tabular}

$<L L D$ below detection 


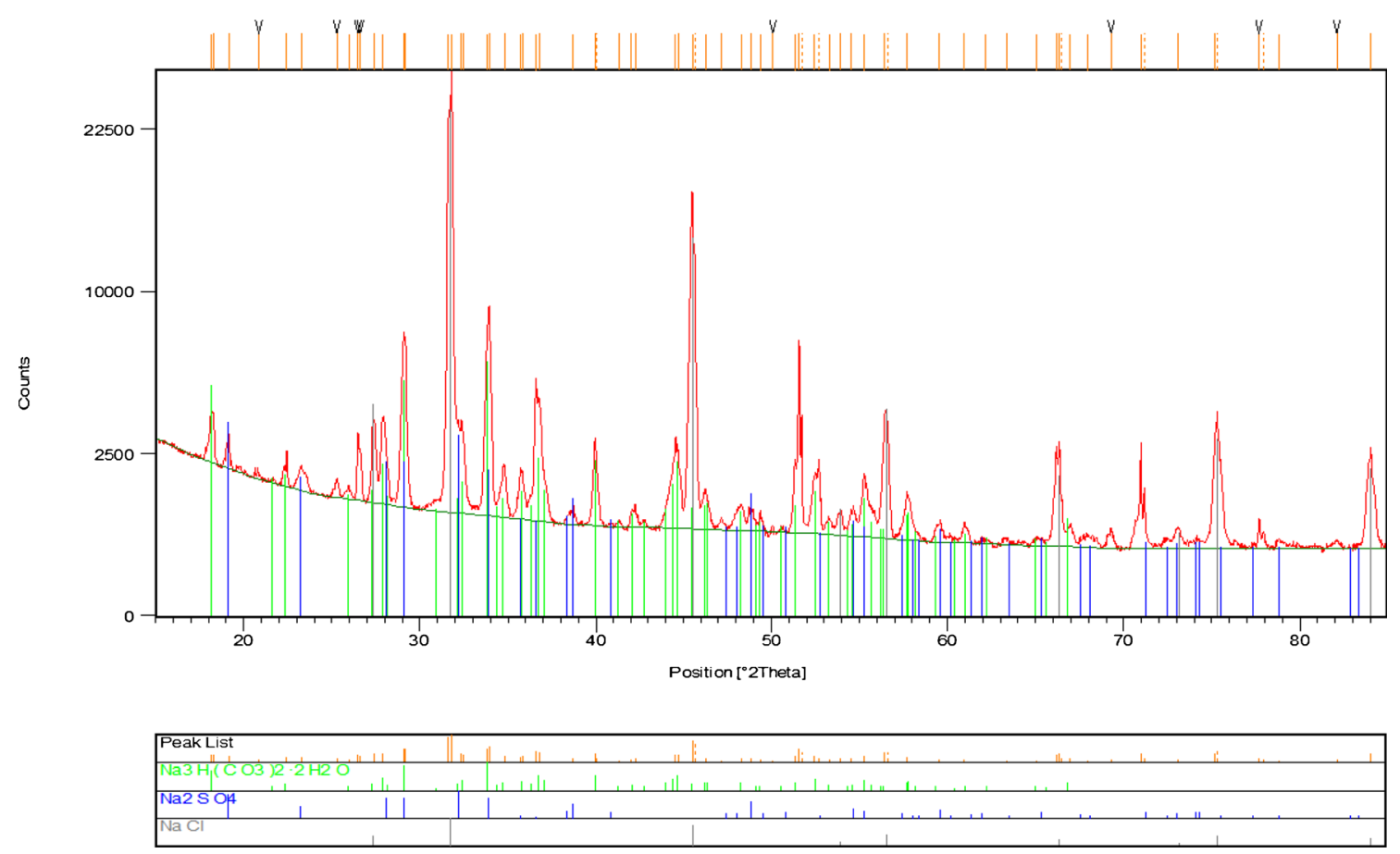

Fig. 1 Mineralogical components of the natron analysed by XRD: trona $\left(\mathrm{Na}_{3} \mathrm{H}\left(\mathrm{CO}_{3}\right)_{2} \cdot 2 \mathrm{H}_{2} \mathrm{O}\right)$, sodium sulphate $\left(\mathrm{Na}_{2} \mathrm{SO}_{4}\right)$ and sodium chloride $(\mathrm{NaCl})$

Analysis of the resulting glass showed the average composition to be $67.5 \mathrm{wt} \% \mathrm{SiO}_{2}, 19.3 \mathrm{wt} \% \mathrm{Na}_{2} \mathrm{O}$ and $10.1 \mathrm{wt} \%$ $\mathrm{CaO}$, which approximates the intended glass composition (Table 6). The composition also confirms that the trona was the only significant reactive component in the natron. The glass produced mimics a typical Roman glass composition of the first to third centuries (Jackson and Paynter 2015), which suggests that such a glass can easily be produced at temperatures of $1100{ }^{\circ} \mathrm{C}$ using these proportions of raw materials in a single stage without natron pre-treatment. Some chlorine is present from the sodium chloride, which is known to aid the glass forming process, and $\mathrm{SO}_{3}$ from the sodium sulphate. A significant proportion of the $\mathrm{K}_{2} \mathrm{O}, \mathrm{Fe}_{2} \mathrm{O}_{3}$ and $\mathrm{Al}_{2} \mathrm{O}_{3}$ in the glass must be contributed by the crucible, despite the crucibles containing a high proportion of chemically resistant and refractory mullite (see alumina-rich crucible composition in Table 2), demonstrating the extremely corrosive nature of the glass. Although $\mathrm{K}_{2} \mathrm{O}$ has been noted in natron from the Wadi Natrun (Fabri and Degryse 2013 quoted in Devulder and Degryse, 2014, 94), very little was detected in the elBarnugi sample. Surprisingly, small concentrations of $\mathrm{MgO}$ $(0.3 \mathrm{wt} \%)$ are present in the glass, which is not present in the sand (Table 1) and scarce in the crucible (Table 2), so a major proportion may be derived from the natron (Table 5). In archaeological glass, the $\mathrm{MgO}$ is often assumed to derive predominantly from the sand.

\section{Characterisation of the model experimental glass}

There was little difference in the soda content of the final model glasses, regardless of the presence or absence of sodium chloride or sodium sulphate in the batch (Table 3). The soda content of the glass was dictated by the amount of sodium bicarbonate added and the conditions used, however, sodium chloride in particular appears to be important for homogenising the batch. With sodium sulphate present, but sodium chloride absent, a thin residue of crystalline sodium sulphate (identified by XRD) was found on the surface of the

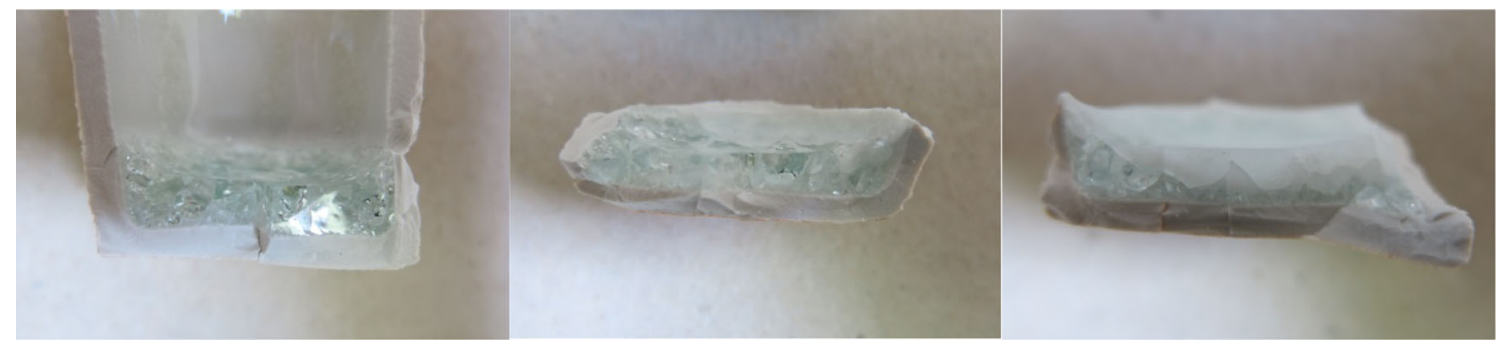

Fig. 2 Batches 1-3 (left to right) show experimental melts made with natron, sand and calcium carbonate melted at $1300^{\circ} \mathrm{C}$ for $12 \mathrm{~h}$. Only batch 1 (left) shows a batch-free glass 
Fig. 3 Glass produced with natron, sand and calcium carbonate melted at $1100{ }^{\circ} \mathrm{C}$ for $12 \mathrm{~h}$ (left, glass in section; right, top view of glass in crucible)
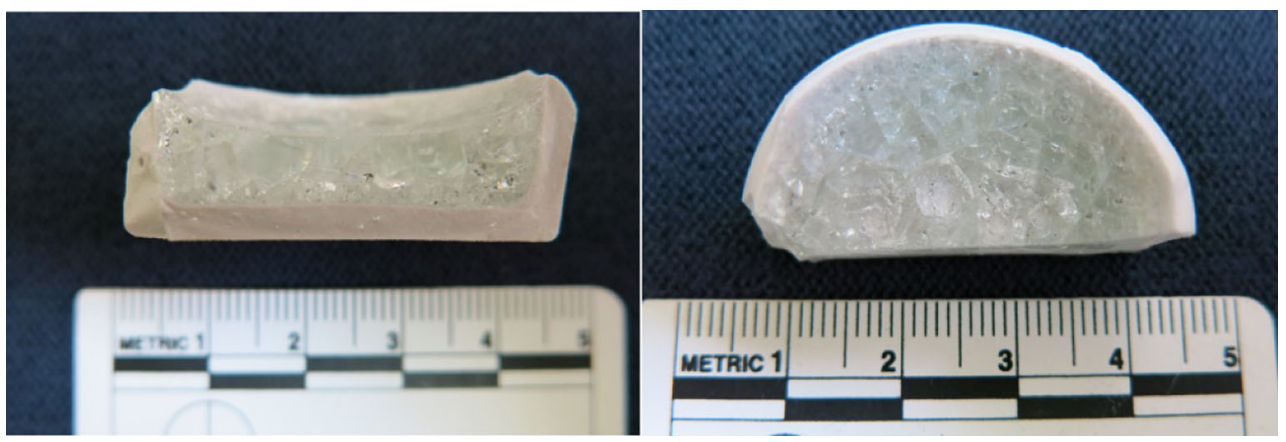

resulting experimental glass and some crystalline phases, predominantly sodium calcium silicate crystals $\mathrm{Na}_{2} \mathrm{O} \cdot 2(\mathrm{CaO})$. $3\left(\mathrm{SiO}_{2}\right)$, were also identified in the melt (Fig. 4). However, when sodium chloride was added, with or without sodium sulphate, the resulting glass was homogenous, there was no residue on the surface, and instead there were numerous bubbles and indications of movement within the melt. In the batch containing sodium chloride, but with sodium sulphate absent, there was also evidence of considerable interaction of the crucible fabric and glass melt, despite the very refractory and chemically resistant nature of the crucibles used. Sodium chloride therefore potentially increases the amount of interaction and contamination from furnace refractories as well (Fig. 5a, b).

These experiments support the previous findings on the limited solubility of chloride and sulphate in the melt, corresponding to the results of Turner (1956) and Tanimoto and Rehren (2008); they also show that the presence of one affects the solubility of the other. Up to $2.6 \mathrm{wt} \%$ chlorine was detected in the melt when sodium chloride alone was added to the batch, but this was reduced to $1.9 \mathrm{wt} \%$ chlorine in the batch that originally contained equal amounts of both sodium sulphate and sodium chloride. Sulphate solubility was also shown to be dependent on the presence of the chlorine, reducing from $1.4 \mathrm{wt} \%$ to $0.6 \mathrm{wt} \% \mathrm{SO}_{3}$ when sodium chloride was present in the batch. The sodium, chlorine and sulphur not accounted for in the final glass were lost as gaseous phases, since there was only a residue on the surface in one instance (the batch without added sodium chloride). These observations show that although the carbonate minerals in natron are primarily responsible for glass formation, the sodium chloride component is likely to have played an important role in producing homogenous, transparent glass, free of crystalline phases or surface residue, particularly in the massive tank furnace installations used for glass production in antiquity. This of course would have been an unconscious but fortuitous outcome for the glassmaker who would recognise natron as a single material.

\section{Discussion}

The el-Barnugi natron has a similar profile of compounds and trace elements to other natron samples previously analysed from the Wadi Natrun (Shortland et al. 2006). When combined with calcium-bearing sand, this natron would produce a glass that was comparable to Roman glasses. Similarly, the boron isotope ratios for the el-Barnugi natron fall within the general range seen for other natron samples from Wadi Natrun. Although none of the boron isotope measurements for Egyptian natron directly matches those measured in Roman glasses, early writings from scrolls (Yardeni 1994, 69) and Pliny's account specify that Egyptian natron was being used in glass production. This mismatch, between the boron composition of the natron samples so far analysed from Egypt and archaeological natron glass, requires further research, but the contribution of the boron present in whichever sand was used to the total amount and boron isotope ratio in the glass is potentially an important and unquantified factor. It is the technological findings relating to glass production, which are most enlightening in this study.

\section{1) Raw material suitability}

Characterisation of the natron from el-Barnugi confirms that the natron is a suitable raw material for glass production, that
Table 6 Composition of the experimental glass made from natron, sand and calcium carbonate (mean of six analyses by SEM-EDS, normalised).

\begin{tabular}{lcccccccccc}
\hline $\mathrm{Na}_{2} \mathrm{O}$ & $\mathrm{MgO}$ & $\mathrm{Al}_{2} \mathrm{O}_{3}{ }^{\mathrm{a}}$ & $\mathrm{SiO}_{2}$ & $\mathrm{P}_{2} \mathrm{O}_{5}$ & $\mathrm{SO}_{3}$ & $\mathrm{Cl}$ & $\mathrm{K}_{2} \mathrm{O}$ & $\mathrm{CaO}$ & $\mathrm{TiO}_{2}$ & $\mathrm{Fe}_{2} \mathrm{O}_{3}$ \\
\hline 19.29 & 0.26 & 1.35 & 67.53 & $<\mathrm{LLD}$ & 0.24 & 0.77 & 0.72 & 10.14 & $<$ LLD & 0.21 \\
\hline
\end{tabular}

$<L L D$ below detection

${ }^{\mathrm{a}} \mathrm{Al}_{2} \mathrm{O}_{3}$ is discounted as it is largely contaminated from the mullite-rich crucible (see Table 2 for crucible composition); this also accounts for some, but not all, of the $\mathrm{K}_{2} \mathrm{O}$ and $\mathrm{Fe}_{2} \mathrm{O}_{3}$ 


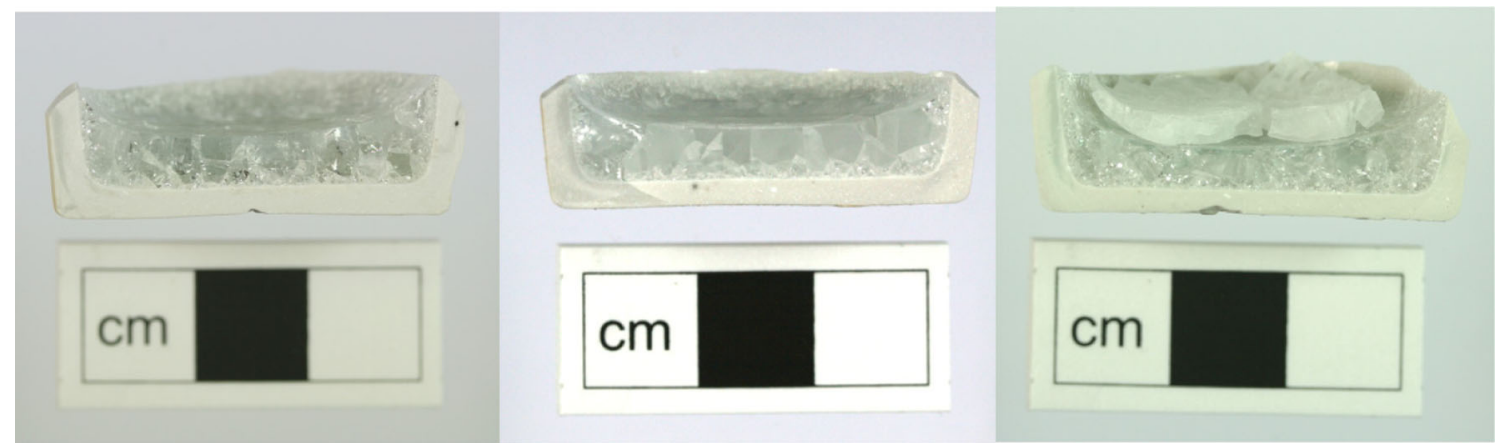

Fig. 4 Model glasses made with sand, calcium carbonate and left to right: sodium chloride, sodium bicarbonate and sodium sulphate (left); sodium bicarbonate and sodium chloride (middle); and sodium carbonate and sodium sulphate (right)

good-quality glass can be produced at $1100{ }^{\circ} \mathrm{C}$, which could be achieved easily in Roman furnaces, and that the reactive soda component is sufficient for it to be an accessible and economically viable flux. It contains a different ratio of minerals and a much higher ratio of reactive component than the flux analysed from the Wadi Natrun, although natron from
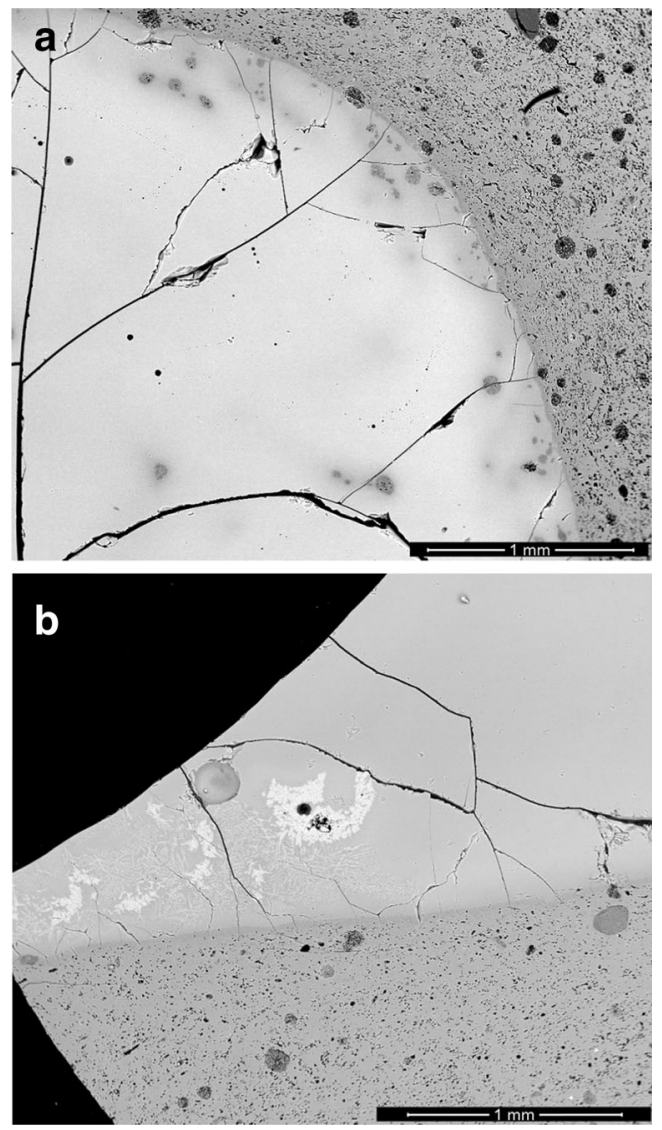

Fig. 5 a SEM image of model glass with sodium bicarbonate and sodium chloride but no sodium sulphate; the glass (bottom left) contains dislodged particles from the mullite-rich crucible (top right) and is enriched in alumina in those areas (darker grey contrast). b SEM image of model glass (top) made with sodium bicarbonate and sodium sulphate but no sodium chloride and crucible (bottom); the glass contains crystalline phases (white) and a residue on the surface (which flaked off prior to sample mounting), but there is less glass/crucible interaction both deposits will demonstrate seasonal compositional variability. The experiment shows the natron will produce a glass without any pre-treatment. It also demonstrated that a large proportion of the natron contributed very little to glass formation, but that even these poorly soluble components played an important role in homogenising and refining the glass, helping to dissolve the batch and disperse any residue that would otherwise remain on the surface after melting.

\section{2) Chlorine and sulphate solubility}

The chlorine and sulphate contents in the experimental natron glass are very similar to the levels observed in colourless Roman glass (Silvestri et al. 2008), allowing for the slightly higher $\mathrm{CaO}$ content in the experimental glasses of this study (Fig. 6). An excess of both sodium chloride and sodium sulphate was present in the natron used to make these reproduction glasses, and so the final levels of chloride and sulphate have been dictated by the solubility of these components at the melting temperature used. A number of studies have investigated how the chlorine content varies in sodium-lime-silica glasses and in particular whether it can be used as an approximate thermometer for indicating the temperature at which

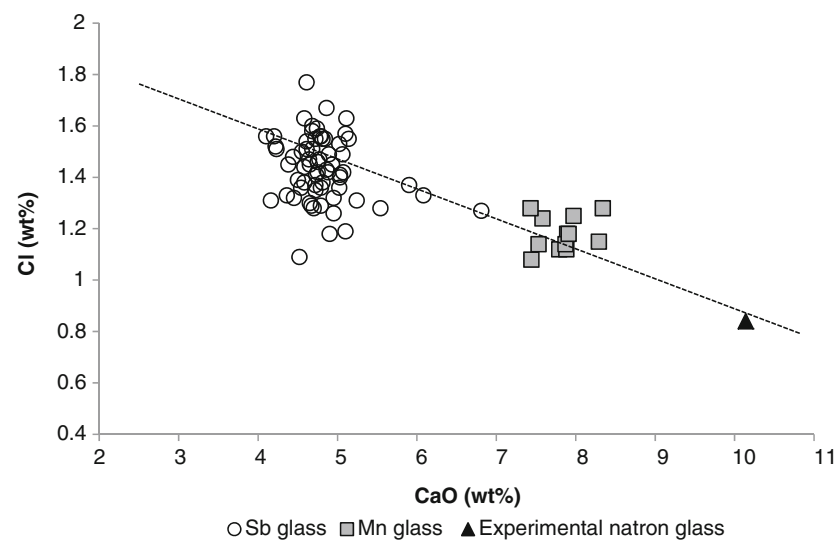

Fig. 6 Plot of the calcium oxide content versus chlorine content of Roman antimony $(\mathrm{Sb})$ and manganese $(\mathrm{Mn})$ decolourised natron glasses (Silvestri et al. 2008), which have different calcium oxide contents, compared to the experimental natron glass 
archaeological glass was produced or worked, and also as an indicator for recycling, for instance by Freestone and Stapleton (2015). Shugar and Rehren (2002) found that this was problematic in practice because the solubility of the chlorine is affected by the glass composition as well. Whilst Freestone and Stapleton (2015) proposed that the sodium oxide content of the glass was an important factor, Shugar and Rehren (2002) and Köpsel (2001) concluded that chlorine solubility was sensitive to the calcium oxide content of the glass (with magnesium and iron oxide concentrations also potentially important). In summary, the chlorine content decreases with increasing melt temperature and is expected to reduce with increasing calcium oxide content. When the chlorine and calcium oxide contents for our natron experimental glass are compared with Roman natron glasses with differing calcium oxide contents, a broad correlation can be observed, suggesting that the temperature used in this experimental work was close to that achieved in antiquity (Fig. 6). There is consistently some spread in the data for ancient glass however, which is not unexpected given the complex and variable composition and processing history (recycling, etc.) of the archaeological examples.

The natron glasses, whether experimental or archaeological, consistently contain lower levels of chlorine than comparable glasses made with laboratory reagents however, despite equivalent temperatures and calcium oxide contents. Similarly, higher than anticipated chlorine contents have been reported for experimental glasses using laboratory reagents in the literature (Bateson and Turner 1939, Shugar and Rehren 2002), allowing for the different temperatures and $\mathrm{CaO}$ contents used in these studies.

This discrepancy could be due to many factors, such as furnace temperature, duration of firing, atmosphere, surface area to volume ratio (laboratorycrucible versus tank furnace) or type of fuel used, but because the distinction appears to be between glasses made with laboratory reagents and ones made with natron, some other quality of the natron itself may be responsible. Firstly the natron contains both sulphate and chloride compounds and this study has shown that the solubility of each in the final glass is lower when both are present in the batch, compared to when only chlorides are present. Secondly the carbonate in the natron was in the form of trona containing combined water, which is anticipated to lower the melt viscosity (Shelby 1997) and so may also affect chlorine solubility.

\section{3) How much natron does it take to produce glass?}

These experimental findings have implications for the amount of natron needed to produce glass. To produce $10 \mathrm{~T}$ of glass with the el-Barnugi natron (where only approximately $40 \mathrm{wt} \%$ of the natron contributes soda for glass formation) would require around $12 \mathrm{~T}$ of natron. This gives a total batch weight, including sand and calcium (in the form of carbonate) of approximately $21 \mathrm{~T}$. This is borne out by the experimental work, where $12.5 \mathrm{~g}$ of natron (in a total batch weight of $21.3 \mathrm{~g}-\mathrm{a}$ ratio of approximately $1.5: 1$ natron/shelly sand) produced $10.4 \mathrm{~g}$ of glass, which is equivalent to $12.5 \mathrm{~T}$ of natron producing $10.4 \mathrm{~T}$ of glass (heated for $12 \mathrm{~h}$ at $1100{ }^{\circ} \mathrm{C}$ ). With the Roman furnaces described by Nenna (2015) at Beni Salama, she calculates the weight of the final glass slab of the western furnace to be approximately 13-20 T (Nenna 2015, 15, using the thickness of existing blocks of glass from Embiez/Bet Shearim); this would make a weight of original batch in the order of 27 to $42 \mathrm{~T}$; this is much larger than the 17-31 batch weight previously anticipated (Freestone in Nenna 2015, 16). This of course assumes that the composition of the natron used at Beni Salama was similar to that described here; it may have had a higher proportion of carbonates.

On the other hand, Pliny's (NH XXXVI, 194) account of glassmaking using sand (from the River Volturno) and mixing it with 'three parts soda, either by weight or by measure' describes an even higher ratio of natron to sand (3:1) than used in our experiments. This suggests a natron deposit which contains around $18 \mathrm{wt} \%$ trona, or alternatively $16 \mathrm{wt} \%$ burkeite, $\mathrm{Na}_{6} \mathrm{CO}_{3} \cdot 2 \mathrm{SO}_{4}$, with the rest probably comprising chlorides or sodium sulphate. This would make a very large original batch size, which would be necessary if the natron had a lower carbonate content, such as the natron analysed from Lake Fazda, Wadi Natrun (Shortland et al. 2011). Pliny collected his information from a variety of sources and authors, with varying familiarity and understanding of the processes described. The accounts are ambiguous in places with respect to the materials and methods, and so it was unclear whether Pliny's phrase 'by weight or measure' could be taken literally. To clarify this comment, the measured density of the elBarnugi natron sample of $1 \mathrm{~g} / \mathrm{cm}^{3}$ was compared to the density of model 'beach' sand (incorporating the calcium in the form of shell), estimated at $1.5 \mathrm{~g} / \mathrm{cm}^{3}$. Based on these densities, the ratio of sodium oxide to silica in the resulting glass would be slightly larger using measurements by weight, as opposed to volume, but not greatly so. It appears that Pliny considered this an adequate level of accuracy, perhaps because the natron would have a variable reactive carbonate content anyway, and so some customisation of the ratios would always have been necessary.

Considering the volume of batch rather than weight, it is also possible to estimate the volume needed to charge the furnace to produce a desired volume of glass. These calculations from the experimental work conducted using natron can only provide a rough guide, but to produce $10 \mathrm{~cm}^{3}$ of glass, the original batch was $47 \mathrm{~cm}^{3}$ in volume, or approximately five times the size. If the very large furnaces at Beni Salama are used as an example (although other known furnaces vary in size and many are smaller), a melting tank of a size of $2 \times 7 \mathrm{~m}$ and a thickness of glass (based on the Bet Shearim 
block) of approximately $0.45 \mathrm{~m}$ would produce a block of glass with a volume of $6.3 \mathrm{~m}^{3}$. The volume of the initial batch therefore would be $29.6 \mathrm{~m}^{3}$, and so the depth of the furnace melting chamber would need to be at least $2 \mathrm{~m}$ to take the entire batch in one loading; otherwise continuous loading would have been required. This is a considerable volume of material, both in terms of the storage requirement before use and of the practicalities of charging the furnace.

\section{Conclusions}

There are multiple significant implications for our understanding of Roman glass technology derived from this research:

1. Natron from el-Barnugi can be used for glassmaking without pre-treatment, lending credence to Pliny's account of the natron glassmaking process arising from the simple heating of lumps of natron in a fire on the beach; glass production using natron was not complex. Therefore, while glassmaking can still be considered specialist in terms of selecting and mixing the correct proportions of raw materials to produce a good-quality glass and the control of furnace temperatures and atmospheres, the experiments conducted here suggest that the materials themselves do not require complex processing before use. Collecting the raw materials, including fuel, and preparing the furnace structures may have been the more labour-intensive part of the process; the glassmaking itself could potentially have been undertaken by a relatively small number of people, which would reduce the time and effort required and ultimately the cost.

2. Natron is not homogenous and not all of the deposit reacts to make a glass. If the natron only contains a small proportion of sodium carbonates, the active compounds for fluxing the glass, then a far larger proportion of natron must be added to the batch. With this improved understanding, the high ratio of natron to sand in Pliny's contemporary descriptions of glassmaking is reasonable. The natron from el-Barnugi contains a higher reactive carbonate component than reported for natron from elsewhere in Egypt such as Wadi Natrun (Shortland et al. 2011), further corroborating Pliny's description of the relative quality of different sources in antiquity. Therefore, various natron sources that have been discounted as unsuitable for glass production can now be reassessed. The approximate parity of the density of natron with that of sand reported here also helps to explain Pliny's previously puzzling phrase 'by weight or measure', particularly as the raw material proportions could never be prescribed exactly beforehand because of their heterogeneity. These experiments demonstrate why the composition of the natron was so important to the glassmakers and justifies the detail given by
Pliny on how to differentiate between various qualities of natron, based on its colour, frothiness, softness, density and even taste (NH XXXXVI, 10).

3. The interpretation of archaeological evidence from natron glassmaking sites can be revised. These experiments demonstrate that despite the high concentration of nonreactive components in the natron, in the form of sulphates and chlorides, no residues remained on the final glass, and so waste scum or 'sandever' is unlikely to be found at natron glass primary production sites (in fact the sodium chloride in the natron appears to play an important role in fining the melt and helps to dissipate the immiscible sodium sulphate surface layer that would otherwise form). Similarly, there may be no diagnostic waste from raw material processing, which may presumably be limited to crushing natron and mixing with the sand and would require little in the way of equipment or additional extra structures. The fact that such a large ratio of natron to sand is required provides clues to the physical operations around a glass furnace and the furnace design. Because a major proportion of the natron is effectively lost as fumes during glass production, this would be accompanied by a substantial reduction in volume to about a fifth of the original batch size on melting. Glassmakers would have needed to allow for this, either by building the furnace chamber considerably deeper than might appear necessary or possibly by constructing the furnaces with a means of continuing charging over a prolonged period, such as openings in the structure which could be resealed to retain the heat (see Nenna 2015, 11).

\section{Implications for Roman glassmaking, organisation and trade}

Research to date suggests that much of the large-scale glass production that took place in the Roman period was based in Egypt and in the Syria-Palestine region of the Eastern Mediterranean, although Pliny mentions other locations as well for which there is little other evidence so far (Shortland et al. 2006). The high-quality glass made colourless with antimony $(\mathrm{Sb})$, which becomes so prolific in the first to third centuries $\mathrm{AD}$, is thought to be the Alexandrian glass of historical accounts, and so a product of Egypt, whereas blue-green glass is described as Judean (Barag 2005, 184, Jackson and Paynter 2015). Assuming that Egyptian natron sources were used to make the glass at many of the furnace sites both inside and outside Egypt, the import of large amounts of natron to glass making furnaces at a distance from the alkali source also needs consideration.

There are clearly logistical considerations to importing the large volumes of natron that we now know were required for each glass batch. To supply sites with tank furnaces where 
large-scale glass production occurred, such as those recently excavated at Jalame (Gorin-Rosen, personal communication), would require at least a tonne of natron for every tonne of glass produced and implies a high level of organisation and well-developed infrastructure. The Roman 'presence' in both Egypt and along the eastern Mediterranean would have facilitated this movement of bulk materials, as it would have the movement of the finished glass, by both sea and land routes (Nenna et al. 1997). Pliny describes Egyptian natron being exported by sea (NH XXXVI, 191), although for what purpose is not stated, in sun-dried, pitch-lined vessels, presumably because natron is easily soluble in water (NH XXXI, 114); another type of natron, from Lydia, was exported as tablets. As natron glass was used to make less valuable utilitarian glassware such as bottles, windows and containers, as well as finer objects (Jackson and Paynter 2015, Silvestri et al. 2008), this suggests that the costs of harvesting and transporting large volumes of natron, to what were effectively competing glassmaking centres in the Syria-Palestine region, were not prohibitive, as there was still profit to be made.

Glassmaking centres outside Egypt would be very vulnerable to any fluctuations in the supply or cost of natron, which might make the glassmakers more economical with its use. More intense competition for the natron might also be expected at times of increased demand for glass, which could be reflected in glass compositions particularly for glasses made outside Egypt; this observation might be supported by the lower ratios of soda to silica and lime, which are consistently found in glass types thought to originate in the Syrio-Palestinian region compared to varieties considered to be Egyptian (Foy et al. 2003, Nenna et al. 1997, Silvestri et al. 2008). Interestingly Pliny (NH XXXI, 114) also states that Egyptian natron was often adulterated with lime, which could be detected by tasting a sample; any additions of this kind would also affect the composition of glass made from exported Egyptian natron, reducing the soda content whilst increasing the lime.

The published compositional data also support changes in natron and glass supplies through time to sites outside Egypt. The Syrian-Palestinian-type composition (high lime and alumina, often some manganese) made in the first century AD has a higher soda to silica ratio than glass from the same region made in subsequent centuries; for example, the sodium concentrations (ca. $18 \mathrm{wt} \%$ ) in the early group 1 glasses analysed by Foy et al. (2003) and the first century AD glass analysed by Gallo et al. (2013) are higher than those in the manganesedecolourised glass (ca. $15 \mathrm{wt} \%$ ) analysed by Silvestri et al. (2008) from the third-century Iulia Felix wreck. This reduction in soda content in the Syrian-Palestinian glasses would coincide with the increase in the scale of the production of antimony-decolourised natron glass, which is likely to have been at sites in Egypt. This increased production of Egyptian glass would potentially have had a substantial impact on the demand for natron.
Together this evidence has demonstrated that high-quality glass could have been produced by glassmakers in the Roman world, using natron in its raw unprocessed form and leaving negligible waste, in a simple one-stage process requiring relatively little labour. However, larger quantities of natron would have been needed than have previously been anticipated, requiring the bulk collection, transport and storage of raw materials and the construction of large furnace chambers or chambers that could be repeatedly charged. This work has further demonstrated that there may have been many different sources available to the Roman glassmaker, which could easily be utilised for glass production, and that the trade in natron to glass-producing areas that did not have their own natron supply must have been highly organised and extensive.

Acknowledgements We would like to thank NERC (NERC OSS/340/ 0207) for the ICP-MS analysis and the NERC ICP-MS facility at the University of Kingston - in particularly, Dr. Beniot Disch for undertaking the analysis and the European Research Council under the Starting Grant scheme (grant agreement no. 240750) for the isotope analysis. We would like to thank Dr. Carol Booth for the analysis of L30A sand, Dr. Darren Swinson of the XRD facility and David Greenfield, MERI, Hallam University, for facilitating the initial XRD analysis. John Burton, University of Sheffield, conducted some initial trial melts on the material for his undergraduate dissertation; his help is appreciated. Professor Glynis Jones made valuable comments on earlier drafts of the paper.

Open Access This article is distributed under the terms of the Creative Commons Attribution 4.0 International License (http:// creativecommons.org/licenses/by/4.0/), which permits unrestricted use, distribution, and reproduction in any medium, provided you give appropriate credit to the original author(s) and the source, provide a link to the Creative Commons license, and indicate if changes were made.

\section{References}

Barag D (2005) Alexandrian and Judaean glass in the price edict of Diocletian. Journal of Glass Studies 47:184-186

Bateson HM, Turner WES (1939) A note on the solubility of sodium chloride in a soda-lime-silica glass. J Soc Glas Technol 23:265-27T

Brems D, Degryse P (2013) Trace element analysis in provenancing Roman glass-making. Archaeometry. doi:10.1111/arcm.12063

Brems D, Ganio M, Degryse P 2014 The Sr-Nd isotopic fingerprint of sand raw materials. In P. Degryse (ed) Glass making in the GrecoRoman world. Studies in Archaeological Sciences 4, Leuven University Press 31-67

Brill RH (1999) Chemical analyses of early glasses. Volume 2: the tables. Corning, New York, p. 480

Cosson AFC 1936 El Barnugi. Bulletin Société Royale D’ArchéologieAlexandrie no. 30-N.S. Vol. IX-1, 113-116

Coulson WDE, Leonard A Jr (1979) A preliminary survey of the Naukratis Region in the Western Nile Delta. Journal of Field Archaeology 6(2):152-168

Décobert C 2003 Le natron égyptien au Moyen-Âge. In D. Foy, M.-D. Nenna eds, Échanges et commerce du verre dans le monde antique, actes du colloque de l'AFAV, Aix-en-Provence, Juin 2001, Instrumentum 24 125-127

Dardeniz G 2015 Was ancient Egypt the only supplier of natron? New research reveals major Anatolian deposits Anatolica XLI. 191-202 
Degryse P (Ed) 2014 Glass making in the Greco-Roman world. Leuven University Press, Leuven

Degryse P, Schneider J (2008) Pliny the Elder and Sr-Nd isotopes: tracing the provenance of raw materials for Roman glass production. J Archaeol Sci 35:1993-2000

Devulder V, Degryse P 2014 Chapter 5: the sources of Natron, in P. Degryse (Ed.) Glass making in the Greco-Roman world. Leuven University Press, Leuven, 87-95. 97-112

Devulder V, Vanhaecke F, Shortland A, Mattingly D, Jackson CM, Degryse P (2014) Boron isotopic composition as a provenance indicator for the flux raw material in Roman natron glass. J Archaeol Sci 46:107-113

Dinnebier RE, Billinge SJL (2008) Powder diffraction theory and practice. Royal Society of Chemistry, Cambridge

Foy D, Picon M, Thirion-Merle V, Vichy M 2003 Caractérisation des verres de la fin de l'Antiquité en Méditerranée occidentale: l'émergence de nouveaux courants commerciaux. In D. Foy, M.D. Nenna eds, Echanges et commerce du verre dans le monde antique, actes du colloque de l'AFAV, Aix-en-Provence, Juin 2001, Instrumentum, 41-85

Freestone IC (2006) Glass production in Late Antiquity and the Early Islamic period: a geochemical perspective. In: Magetti M, Messiga B (eds) Geomaterials in cultural heritage, 201-216. Geological Society, London

Freestone IC, Stapleton CP (2015) Composition of mosaic glass vessels of the early Imperial period. In: Bayley J, Freestone IC, Jackson CJ (eds) Glass of the Roman world. Oxbow Books, Oxford, pp. 62-77

Gallo F, Silvestri A, Molin G (2013) Glass from the Archaeological Museum of Adria (North-East Italy): new insights into Early Roman production technologies. J Archaeol Sci 40:2589-2605

Ignatiadou D, Dotsika E, Kouras A, Maniatis Y 2005 Nitrum chalestricum: the natron of Macedonia. Annales du 16e Congres de l'Association Internationale pour l'Histoire du Verre 16, London 2003, 16 64-67

Jackson CM, Smedley JW (2004) Medieval and post-medieval glass technology: melting characteristics of some glasses melted from vegetable ash and sand mixtures. Glass Technol 45(1):36-42

Jackson CM, Paynter S (2015) A great big melting pot: exploring patterns of glass supply, consumption and recycling in Roman Coppergate, York. Archaeometry. doi:10.1111/arcm.12158

Jones HL 1928 (translation). The geography of Strabo, volume VII, book XVI. Harvard University press, Loeb Classical Library, Harvard Massachusetts

Köpsel D 2001 Solubility and vaporization of halides. In Proc. Int. Congr. Glass, Volume 2. Extended Abstracts, Edinburgh, 2001. Society of Glass Technology, Sheffield. P 330

Lucas A (1912) Natural soda deposits in Egypt. Survey Department Press, Cairo

Lucas A (1932) The occurrence of natron in ancient Egypt. J Egypt Archaeol 18(1/2):62-66

Lucas A, Harris JR (1962) Ancient Egyptian materials and industries, 4th edn. Edward Arnold, London

Nenna M-D, Vichy M, Picon M (1997) L'Atelier de verrier de Lyon, du 1 er siècle après J.-C., et l'origine des verres "Romains". Revue d'Archéométrie 21:81-87
Nenna M-D, Vichy M, Picon M, Thirion Merle V 2005 Ateliers primaires $\mathrm{du}$ Wadi Natrun: nouvelles découvertes. Annales du $16^{\mathrm{e}}$ congrès de l'association Internationale pour l'Histoire du Verre (London 2003), Nottingham: AIHV, 56-63

Nenna M-D (2015) Primary glass workshops in Graeco-Roman Egypt: preliminary report on the excavations of the site of Beni Salama, Wadi Natrun (2003, 2005-9). In: Bayley J, Freestone IC, Jackson CM (eds) Glass of the Roman world. Oxbow Books, Oxford, pp. 122

Parkinson J (1914) The East African trough in the neighbourhood of the Soda Lakes. Geogr J 44(1):33-46

Paynter S, Kearns T, Cool H, Chenery S (2015) Roman coloured glass in the Western provinces: the glass cakes and tesserae from West Clacton in England. J Archaeol Sci. doi:10.1016/j.jas.2015.07.006

Pearce NJG, Perkins WT, Westgate JA, Gorton MP, Jackson SE, Neal CR, Chenery SP (1997) A compilation of new and published major and trace element data for NIST SRM 610 and NIST SRM 612 glass reference materials. Geostandards Newsletter. The Journal of Geostandards and Geoanalysis 21(1):115-144

Pliny: natural history. Volumes VIII (translated by W.H.S. Jones, 1963) and X (translated by D.E. Eichholz, 1962) Loeb Classical Library, Cambridge, Massachusetts

Rehren T (2000) Rationales in Old World base glass compositions. J Archaeol Sci 27(12):1225-1234

Shelby JE (1997) Introduction to glass science and technology. Royal Society of Chemistry, Hertfordshire

Shortland A (2004) Evaporites of the Wadi Natrun: seasonal and annual variation and its implication for ancient exploration. Archaeometry 46:497-516

Shortland A, Schachner L, Freestone I, Tite M (2006) Natron as a flux in the early vitreous materials industry: sources, beginnings and reasons for decline. J Archaeol Sci 33:521-530

Shortland A, Degryse P, Walton M, Geer M, Lauwers V, Salou L (2011) The evaporitic deposits of Lake Fazda (Wadi Natrun, Egypt) and their use in Roman glass production. Archaeometry 53(5):916-929

Shugar A, Rehren TH (2002) The composition of Egyptian glass as a function of melting temperature. Proc. XIX Int. Congr. Glass, Edinburgh, 1-6 July 2001. Glass Technol 43C:145-150

Silvestri A, Molin G, Salviulo G, Schievenin R (2006) Sand for Roman glass production: an experimental and philological study on source of supply. Archaeometry 48(3):415-432

Silvestri A, Molin, G. and Salviulo, G. (2008) The colourless glass of Iulia Felix. J Archaeol Sci 35(2):331-341

Smedley JW, Jackson CM (2002) Medieval and post-medieval glass technology: batch measuring practices. Glass Technol 43(1):22-27

Tanimoto S, Rehren T (2008) Interactions between silicate and salt melts in LBA glassmaking. J Archaeol Sci 35:2566-2573

Turner WES (1956) Studies in ancient glasses and glassmaking processes, part V; raw materials and melting processes. J Soc Glas Technol 40:277-300T

Wikinson JG (1843) Some account of the Natron Lakes of Egypt. Journal of the Royal Geographical Society 13:113-118

Yardeni A (1994) Maritime trade and royal accountancy in an erased customs account from 475 B.C.E. On the Ahiqar scroll from elephantine. Bull Am Sch Orient Res 293:67-78 